\title{
POLÍTICA CONTRARREFORMISTA E IMAGEN ANTI-LUTERANA EN NUEVA ESPAÑA
}

\author{
POR \\ ALICIA MAYER \\ UNAM-Instituto de Investigaciones Históricas \\ amayer@unam.mx
}

RESUMEN

Este trabajo analiza el pensamiento político de la Contrarreforma en el contexto del México colonial. En la sociedad novohispana, la figura del reformador alemán, Martín Lutero sirvió no sólo como un elemento de propaganda contra la reforma protestante, sino como antítesis de los valores culturales e ideológicos de los católicos novohispanos, principalmente de los criollos. Consecuentemente aquí se analiza la ideología contrarreformista y sus valores a través del discurso anti luterano desde el punto de vista historiográfico, el teológico y el iconográfico.

PALABRAS CLAVE: Pensamiento político, Reforma, Contrarreforma, ideología, México Colonial, Lutero

\section{COUNTERREFORMATION POLITICS AND THE ANTI-LUTHERAN IMAGE IN NEW SPAIN}

\begin{abstract}
This paper analyzes the political thought of the Counterreformation in the context of Colonial Mexico. In colonial society, the image of the German reformer Martin Luther served not only as an element of propaganda against the Protestant Reformation, but also as the antithesis of Catholic Colonial cultural and ideological values, mainly of the creoles. Consequently here the Counterreformation ideology and values is analyzed through the anti-Lutheran discourse from the historiographical point of view, theological and iconographic.
\end{abstract}

KEY WORDS: Political Thought, Reformation, Counterreformation, Ideology, Colonial Mexico, Luther.

Recibido/Received 19-12-2014

Aceptado/Accepted 30-07-2015

\section{INTRODUCCION}

El fenómeno histórico de la Contrarreforma -y ya se discutirá aquí más adelante sobre la pertinencia de llamarle así- es un tema de estudio actual en parte por su carácter "global", si se nos permite utilizar esta palabra tan de moda en el siglo XXI, así como por su larga duración, término braudeliano que remite a la amplia temporalidad del desarrollo de un proceso del devenir humano. Dicho movimiento no sólo se prolonga por un espacio muy grande de tiempo, sino que también tuvo efectos trascendentes en la visión del mundo y en la cultura, por no hablar de la conformación de una identidad propia, en las naciones que lo adoptaron, aquende y allende el Atlántico.

La Reforma protestante del siglo XVI propició un gran vuelco religioso y el consiguiente quiebre espiritual de la cristiandad que quedó escindida en dos mitades antagónicas: la protestante y la católica. Ante la severa crisis causada por este hecho, en el año de 1545 se convocó el
Concilio de Trento destinado a darle solución a los problemas institucionales y misionales del momento. Las reuniones se llevaron a cabo de manera intermitente hasta 1563 y en conjunto se trata de "la gran reflexión colectiva de la Iglesia". ${ }^{1}$ Sus decretos reorganizaron la institución a partir de una reafirmación y explicación definitiva de la doctrina católica, de una propuesta para una reforma religiosa profunda, en el terreno doctrinal, así como de la moral y de la conducta del clero y del pueblo cristiano que cubrió muchos ámbitos. Uno de sus principales objetivos fue naturalmente el de tratar los asuntos eclesiásticos y doctrinales surgidos por la Reforma protestante. ${ }^{2}$ La Iglesia católica se

1 Mora Mérida, 1990. "Reflexiones históricas acerca del pasado idolátrico hispanoamericano en el siglo XVI", en Josep I Saranyana, P. Tineo y Anton Pozas (coords), Evangelización y Teología en América (siglo XVI): 690.

2 Las disposiciones resultantes de Trento fueron las siguientes: Se condenó la doctrina luterana sobre el pecado original y la justificación; 
alzó a partir de entonces como la custodia e intérprete de la Palabra revelada, como mediadora y transmisora de la gracia a través de la administración de los sacramentos y como enemiga del protestantismo, por lo que se justificó darle el nombre de Contrarreforma al movimiento que emanó de ella. El Concilio de Trento restauró manifestaciones de espiritualidad medieval y dio plena libertad a todos los estamentos sociales para la devoción comunitaria, con excesos sentimentales y una comprensión supersticiosa de la devoción. Como respuesta al reto del protestantismo, en una especie de reacción obsesiva, el catolicismo subrayó las formas externas de religiosidad: las procesiones, la veneración de los santos, la intercesión por las almas del purgatorio, las indulgencias, etcétera, que se convirtieron verdaderamente en signos de fe. ${ }^{3}$

Junto con Roma, pero no necesariamente al unísono con ella, España se proclamaría como la enemiga acérrima de los estados que habían aceptado la confesión protestante. Después del Concilio de Trento se impuso una Iglesia defensiva y militante en la Península ibérica sobre otras pautas espirituales. ${ }^{4}$

La monarquía hispana se valió de la religión como el sólido cimiento del dominio político. Por la situación histórica que resultó de dicho proceso, surgió un esquema espiritual adaptado a un proyecto político, basado en la unidad religiosa y animado por una idea providencialista que haría de la monarquía de los Austrias la gran defensora de la religión católica. Desde el siglo XVI este conflicto de grandes dimensiones rebasó los confines europeos con la expansión ultramarina y tuvo un eco muy sonoro en el nuevo continente, lo que marcó, asimismo, el derrotero de la colonización americana. ${ }^{5}$ La evangelización de las Indias fue vista por los tratadistas como compensación de las pérdidas que la Iglesia sufría en Europa. ${ }^{6}$ El arzobispo-virrey Juan de Palafox llegó a afirmar en el siglo XVII que el Descubrimiento de América había tenido el fin divino "de hacer más extendida la fe y más gloriosa y triunfante la Iglesia católica", 7 para recordar que la causa espiritual y política de España no tenía parangón.

Se debe tener muy presente que la Reforma protestante y la conquista militar y espiritual de América fueron hechos contemporáneos y ambos causaron una revolución histórica

se definió la doctrina católica; la Iglesia se adhirió a la tradición de la Biblia así como de las autoridades; se aceptó el texto latino de la Vulgata como traducción oficial de las Escrituras; se otorgó una situación privilegiada a la filosofía tomista; se insistió sobre el celibato sacerdotal; se señaló la reforma del clero, se fortificó el poder episcopal y se dio primacía de la jerarquía secular sobre las órdenes. Ver Lynch 1973 I: 319. Balderas Vega, Gonzalo 1996. La Reforma y la Contrarreforma. Dos expresiones del ser cristiano en la Modernidad: 4 México: Universidad Iberoamericana.

3 Rubial, Antonio. 1999. La santidad controvertida: 58 México: Fondo de Cultura Económica.

4 Fernández Álvarez, Manuel. 1998. Felipe II y su tiempo: 39ss Madrid: Espasa Calpe.

5 Mayer, Alicia y María Alba Pastor (coords). 2000. Formaciones religiosas en la América colonial: 13-37 México: Universidad Nacional Autónoma de México, Facultad de Filosofía y Letras.

6 Frost, Elsa Cecilia. 2002. La historia de Dios en las Indias: 239 México: Tusquets Editores.

7 Palafox y Mendoza, Juan. 1946. Ideas políticas: cap. I México: Universidad Nacional Autónoma de México. sin precedentes que tuvo grandes repercusiones en ambos lados del Atlántico. Cuando el Estado y la Iglesia se extendieron hacia América, la labor espiritual estuvo íntimamente ligada a la política. Conforme al proyecto que fijó la corona para todo su imperio, también en la Nueva España se buscó la uniformidad de la fe y el culto, además de determinarse la forma de vivir de la sociedad mediante reglas y normas de regulación y de control. Las instituciones llevaron a cuestas la crisis religiosa heredada de Europa que en el Nuevo Mundo se manifestaría también en varios ámbitos de la vida colonial, pero, con distintos matices de acuerdo con las características y circunstancias locales determinadas por los elementos criollo, indígena y africano que le dieron su impronta y la diferenciaron de España.

Al igual que en Europa, surgió en la América hispana un rígido formalismo en los campos del dogma, de las formas litúrgicas, del derecho canónico y de las estructuras administrativas. También este mundo heredó la rivalidad teológica contra el protestantismo, sentimiento que se mostró en los discursos, en el imaginario religioso y en la memoria colectiva de la época. Las interpretaciones que ofrecen los teólogos, los clérigos, los historiadores, los inquisidores, los autores espirituales, los legos, los poetas y artistas del México colonial revelan cabalmente la espiritualidad y el pensamiento de la Nueva España. El fin de este trabajo es presentar un panorama de cómo se implementó y se manifestó el espíritu contrarreformista en el ámbito del pensamiento en Nueva España.

Si bien el fin de este trabajo es presentar un panorama de cómo se implementó y se manifestó el espíritu contrarreformista en el ámbito del pensamiento en Nueva España, no es éste el espacio para llevar a cabo un análisis tan amplio en extensión y profundidad sobre todos los actores que intervinieron para apuntalar la Contrarreforma en las tres centurias del México virreinal, que desbordaría cualquier pretensión más ambiciosa. La temática esbozada ahora se deriva, en parte, de la investigación realizada hace algunos años en la obra Lutero en el Paraíso, ${ }^{8}$ de la Reforma católica en el México colonial, desde la perspectiva del rechazo al protestantismo, y conviene señalar que la línea de este trabajo se ciñe a esa misma cadena causal, misma que se refleja en cada apartado. En esa retrospectiva hemos dejado fuera a alguno de esos actores -las órdenes religiosas, por ejemplo- cuya participación merece, por su complejidad y extensión, un estudio aparte, que, debe decirse, han logrado con notables resultados un nada despreciable número de historiadores. ${ }^{9}$

\section{¿CONTRARREFORMA EN MÉXICO?}

Para avanzar en nuestro estudio, es necesario reflexionar, primero, sobre el concepto de "Contrarreforma", que comenzó a ser utilizado en el siglo xIX para denotar la reacción del catolicismo frente a la Reforma protestante y

8 Mayer, A. 2008.

9 Sólo por mencionar a algunos: Gómez Canedo, 1977; Morales Valerio, 1973; Nettel, 1986; Ricard, 1986; Mora Mérida, 1990; Huerga, 1990; Blancarte, 1992; Brading, 1997; Lara Cisneros, 2005. 
después ver si tal concepto se puede aplicar a la realidad del México colonial. No podemos menos que advertir que existe una problemática en la historiografía reciente en torno al uso de este término. ${ }^{10}$ Para Ricardo García Villoslada, toda la historia de la Iglesia en el siglo XVI podría ser estudiada a la luz del sólo concepto de Contrarreforma, cuya significación abarca tanto los esfuerzos de renovación interior, cuanto los intentos de reconquista exterior. ${ }^{11} \mathrm{El}$ historiador mexicano, Enrique González González no duda en emplear el concepto de Contrarreforma y en situarlo en el contexto de Nueva España. Se refiere a que este movimiento fue un doble llamado a imponer el orden rígido en lo doctrinal y en la estructura de la jerarquía eclesiástica y fue asimismo una doble fórmula autoritaria que sumaba el absolutismo real y la verticalidad en materia religiosa. ${ }^{12}$ Por su parte, Melquíades Andrés, en su libro Reforma española y Reforma luterana afirmaba enfáticamente que...

Necesitamos superar el concepto de Contrarreforma acuñado a fines del siglo XVIII por la historiografía alemana de la llustración y generalizado en la segunda mitad del siglo XIX por Ranke. La historiografía europea ha llamado Reforma al protestantismo y Contrarreforma a la restauración católica, presentada aquí como pura reacción frente a la protestante y encarnada de modo especial por España en los siglos XVI y XVII. ${ }^{13}$

Es innegable que la tendencia reformista dentro del catolicismo se dio en Europa antes de que fuera conocido Martín Lutero, con distintos movimientos de renovación desde la Edad Media y el Renacimiento. Estas corrientes innovadoras se sumaron a principios del siglo XVI a la urgencia de clarificar los dogmas y de responder a ingentes necesidades espirituales. Después, con Trento, se llevaron a cabo profundas reformas eclesiásticas y religiosas al mismo tiempo que luchas apasionadas contra la herejía.

Desde luego que hoy en día el concepto del historiador Leopold von Ranke de "Contrarreforma como reacción a la Reforma" se ha superado. Algunos autores han dado otras alternativas para entender el proceso. En 1958 Walter Zeeden habló de la "formación de confesiones" (Konfessionsbildung) o de la "época confesional". ${ }^{14}$ Heinz

10 Geoffrey R. Elton, menciona la "disputa” entre los historiadores por Ilamarle al resurgimiento católico "Contrarreforma" o Reforma católica. Elton, Geoffrey R. 1963. Reformation in Europe. 1517-1559: 180181 London: Collins. Para la polémica en la propia Alemania, ver Lutz, H. 1983. Das Ringen um deutsche Einheit und kirchliche Erneuerung, 14901648,: 320-327 Berlin: Propyläen Verlag.

11 García Villoslada, R. 1959. "La Contrarreforma. Su nombre y su concepto histórico", en Saggi storici intorno al papato dei professori della Facoltá di Storia Eclesiástica: 189-242 Roma: Miscellanea Historiae Pontificae XXX, 1.

12 González González, E. 2005. "La ira y la sombra. Los arzobispos Alonso de Montúfar y Moya de Contreras en la implantación de la Contrarreforma en México", en M. del Pilar Martínez López-Cano y F. Javier Cervantes Bello, Los Concilios Provinciales en Nueva España. Reflexiones e influencias: 93-94 México: Universidad Nacional Autónoma de México, Instituto de Investigaciones Históricas, Benemérita Universidad Autónoma de Puebla.

13 Andrés Martín, Melquíades. 1975. Reforma española y Reforma luterana: 4 Madrid: Fundación Universitaria Española.

14 Zeeden, Ernst W. 1932. "Grundlagen und Wege der Konfessionsbildung in Deutschland im Zeitalter der Glaubenskämfe", en Historische Zeitschrift, 185: 249-299.
Schilling y Wolfgang Reinhard acuñaron en los años ochenta y noventa del siglo xx el término de "confesionalización", que se ciñe a una fase formativa básica de la teología y de la estructura eclesial. ${ }^{15}$ Ésta se caracterizaría dentro de la Iglesia por tener un cuerpo dogmático y ritual, disciplinamiento del clero y de la sociedad, asunción de valores comunes mediante la educación, etcétera. Debe distinguirse, sin embargo, entre los conceptos de "Contrarreforma" y de "Confesionalización", aunque van muchas veces ligados. La Contrarreforma se refiere al proceso reformador de la estructura de la Iglesia católica al mismo tiempo que implica el rechazo y combate al protestantismo, según se ha dicho. La confesionalización, por otro lado, apunta a una consolidación de la fe, ya sea la católica o la protestante según el caso de cada nación, de manera más firme en las regiones donde se impusieron estos credos. El México colonial, a la par con las tendencias reformadoras tridentinas, refleja un espíritu contrarreformista, palpable en distintos ámbitos y expresado en diversas formas que mencionaremos aquí. Para entender el proceso, éste deberá ser analizado dentro de la concepción general del proyecto imperial hispánico.

Antonio Sáez Arance ha cuestionado la aplicabilidad del concepto de "confesionalización" a la realidad de la América hispana colonial bajo el dominio de los Habsburgo, ${ }^{16}$ ya que éste surge en el contexto de la discusión sobre el desarrollo sociorreligioso, político y cultural europeo. Además, aduce que la realidad indígena propuso retos al proceso de formación y consolidación de las estructuras confesionales que nos hacen dudar si en México afianzaron dichas estructuras y hasta qué punto fue completamente exitosa la política contrarreformsita. Gerardo Lara Cisneros ha estudiado con profundidad el tema, por ejemplo, de las idolatrías (rendir culto a un ídolo o falso dios) y otro tipo de heterodoxias, ${ }^{17}$ que se presentaron como nuevos retos para la Iglesia en Indias y que fueron particularmente persistentes. Los naturales caían en este tipo de delito de fe, pero dada su condición de población vulnerable, siguieron bajo la jurisdicción de los prelados y fueron, pues, atendidos no por la Inquisición, sino por los obispos, cuyas acciones fueron reguladas por el derecho canónico y las disposiciones conciliares ecuménicas. ${ }^{18}$

Por su parte, Hans Jürgen Prien ha observado que al espíritu contrarreformista hispanoamericano le faltó el trasfondo de una realidad protestante. Si bien esto es cierto, empero, podemos observar, por ejemplo, que aunque los

15 La obra de estos autores se cita en la bibliografía general.

16 Sáez-Arance, A. 2001. “¿'Confesionalización' en la América Hispana? Observaciones sobre la aplicabilidad de un concepto", en Héctor Noejovich (ed.), América bajo los Austrias. 50 Congreso Internacional de Americanistas 2000: 75-80 Pontificia Universidad Católica de Perú.

17 O bien, crímenes de fe, como la bigamia, las transgresiones sexuales, la práctica de otras supersticiones como la hechicería y otros. Lara Cisneros, Gerardo, 2015. "La lucha contra la superstición y las idolatrías en Nueva España y Perú. Siglo XVII”, en José de la Puente Brunke y Alicia Mayer, Iglesia y sociedad en la Nueva España y el Perú, México, Lima Madrid, Analecta Editorial-Universidad Pontificia de Perú, Universidad Nacional Autónoma de México, Centro de Estudios Mexicanos.

18 Ibídem: 138-139. Ver también David Tavárez, The Invisible War. Indigenous Devotions, Discipline and Dissent in Colonial Mexico, 2011. 
Concilios Provinciales que se llevaron a cabo en México no hacen referencia directa a la herejía luterana, sin embargo, ya en las primeras páginas de los decretos del Primer Concilio se hace alusión al carácter militante de la Iglesia americana y se establece que ésta es enemiga del demonio y que luchará denodadamente contra él. ${ }^{19}$ Stafford Poole acepta que la Contrarreforma estuvo presente en el Nuevo Mundo, con su afán de globalidad y coherencia, y sus pretensiones organizativas y estructurales. ${ }^{20}$

En el estudio que realicé hace algunos años, Lutero en el Paraíso, ${ }^{21}$ donde se hace un análisis general de la Contrarreforma en el México colonial, pude concluir que sí hubo una vinculación de Hispanoamérica con el desarrollo sociorreligioso, político y cultural de la propia España y que el virreinato resultó ser parte esencial del eslabón del mundo hispánico, aunque aquí las circunstancias motivaron también a que se diera un proceso sui generis en el desarrollo de la religiosidad. Como mundo hispánico que era, la América española se convirtió en un espacio de ampliación cultural, en una parte de la esfera de influencia de la reacción católica y, por ende, ofreció un frente ideológico común con la metrópoli, en contra de la Reforma protestante. Nueva España se alió con la Corona y la Iglesia y absorbió el espíritu militante del proyecto ecuménico del catolicismo romano en una campaña que tuvo, por ende, alcances mundiales.

En suma, si bien es verdad que existió una reforma profunda y original dentro del ámbito católico hispánico, que impactó en sus dominios coloniales, no es menos cierto que éstos heredaron también el rechazo a la reforma luterana y reaccionaron frente a ella con distintos instrumentos a su alcance. El Estado español se agenció el derecho de librar a sus súbditos del otro lado del Atlántico de la heterodoxia y de aislarlos de toda contaminación herética. La consigna fue reservar terrenal y espiritualmente las posesiones ultramarinas para el catolicismo, al mismo tiempo que se llevaba adelante el esfuerzo misional evangelizador con los indios.

En Nueva España la Contrarreforma se impuso gracias a instituciones y a grupos que hicieron posible la formación de una cultura autoritaria, aunque con un enorme poder de adaptación a las circunstancias locales: éstos fueron un clero secular culto, egresado de los colegios jesuíticos y seculares, así como de la universidad y apoyado por los cabildos catedralicios y por los obispos, quienes por medio de los concilios provinciales, aplicaron las reformas propuestas por Trento a la situación colonial; el tribunal del Santo Oficio, instalado oficialmente en 1571, encargado de vigilar la ortodoxia y las buenas costumbres; la Compañía de Jesús, cuyos primeros miembros arribaron en 1572 al virreinato e impulsaron una nueva espiritualidad, flexible y sincrética y llevaron a cabo una labor educativa trascendente; las provincias

19 Biblioteca Bancroft. Universidad de California, Berkeley (en adelante, BLB). Mexican Manuscripts (en adelante M-M), 266.

20 Poole, Stafford. 1990. "Incidencia de los Concilios Provinciales Hispanoamericanos en la organización eclesiástica del Nuevo Mundo", en Josep I. Saranyana y P. Tineo (coordinadores), Evangelización y teología en América (siglo XVI), 2 vols: 551 X Simposio Internacional de Teología, Pamplona, Universidad de Navarra.

21 Mayer, Alicia. 2008. Lutero en el paraíso. La Nueva España en el espejo del reformador alemán, México: Fondo de Cultura Económica. de carmelitas, dieguinos y mercedarios, fundadas para la predicación en el ámbito urbano y los conventos de religiosas para dar cabida al sector femenino criollo cada vez más numeroso. Aquí mencionaremos algunos de estos agentes y revisaremos brevemente los dos aspectos de la reforma católica en Nueva España, el de depuración y el militante.

\section{LA CONDENA AL PROTESTANTISMO Y LA IMAGEN DE LUTERO}

Antes de hablar de la vertiente reformadora postridentina, veremos su aspecto militante. Las instituciones virreinales se sumaron al ataque contra la herejía, orquestada desde España, aún cuando no había aflorado en los reinos de ultramar una corriente herética como en Europa. Nueva España se sumaría a la gran confederación contra los infieles y cismáticos, con la salvedad de que aquí las autoridades tuvieron literalmente que buscar debajo de las piedras alguno que otro heterodoxo a quien culpar de protestante. En comparación con los grupos perseguidos de Valladolid, Granada y Sevilla en el siglo XVI, pocos serían señalados del otro lado del Atlántico como luteranos, nombre genérico que se les dio a todos los sospechosos de abrazar alguna de las confesiones protestantes.

Desde España, se dio una campaña represiva contra el protestantismo para evitar que brotara en las colonias mientras que en éstas la hubo para que en caso de encontrarse sus manifestaciones, fueran rápidamente erradicadas. Se advertía sobre la necesidad de prevenir el "contagio" de la heterodoxia en América por el influjo de algunas de estas corrientes desde Europa, sobre todo en lo tocante a los indios, recientemente en proceso de incorporación a la grey cristiana por medio de la evangelización. En 1555, el arzobispo Alonso de Montúfar a México, ordenaba vigilar la eficacia de la revisión de las costas y barcos porque desde Madrid llegaban persistentes recomendaciones en este sentido: "Que a los comisarios de los puertos de mar se les dé particular instrucción de cómo se ha de hacer la visita de navíos extranjeros en los que se presume que vienen infeccionados de la secta de Lutero." 22 Montúfar escribiría a Felipe II en 1561: "Bendicto Dios, Nuestro Señor, que en lo que toca a la pestilencia luterana esta tierra está buena, hasta agora muy poco se ha sentido en ella, y eso poco que ha habido, con el favor de Nuestro Señor luego se ha puesto remedio en atajallo." 23

El México colonial estuvo ligado al compromiso de la monarquía española de erigirse en adalid de la ortodoxia católica apostólica romana y en defensa de sus antiguas tradiciones de devoción y prácticas piadosas. El propósito era desterrar todo brote de reforma religiosa de cuño protestante, asentar con firmeza la autoridad episcopal y regalista de la Iglesia española que propugnaba por la estricta observancia de la legislación canónica, mantener el aparato ceremonial y ritual, respetar la tradición y las costumbres de

22 Contreras, J. 1984. (sin título), en Pérez Villanueva, Joaquín y Bartolomé Escadell Bonet (dirs). Historia de la Inquisición en España y América: 760. 2 ed., Madrid: Biblioteca de Autores Cristianos.

${ }_{23}$ Gringoire, Pedro (Gustavo Báez Camargo). 1961. "Protestantes enjuiciados por la Inquisición”, en Historia Mexicana, vol XI, núm. 2: 161. 
devoción popular así como reducir a los indios al catolicismo bajo la intervención diocesana.

Por sorprendente que parezca y, pese a la lejanía geográfica y a lo ajeno que resultaba el mundo germano para la Nueva España, en el ámbito colonial sí hubo una respuesta contundente al movimiento religioso y teológico iniciado por Martín Lutero en el siglo XVI. El reformador alemán fue tema de interés de los historiadores y cronistas desde la segunda mitad de esa centuria. Su imagen se forjó en los procedimientos de expresión y representación entonces en uso, principalmente en textos impresos, en manuscritos, en sermones y en la iconografía. A través de un discurso permanente y persuasivo que lo colocó en la picota propagandística del catolicismo postridentino, fue exhibido como el mayor enemigo de la fe. Lutero se convirtió en una figura arquetípica, opuesta a las posturas paradigmáticas del catolicismo de la Contrarreforma. Fue considerado el paradigma del mal, se le asociaron elementos negativos, se le ubicó fuera de su contexto y todo ello permeó profundamente en la psique como resultado de herencias y estereotipos provenientes de España. Naturalmente se condenó su propuesta teológica. Lutero se apartó de la Iglesia cuando cuestionó la validez tradicional del sacramento de la penitencia, cuando amenazó seriamente la autoridad pontificia y la jerarquía eclesiástica. Con su doctrina de la gracia irresistible, negó el carácter intrínseco de los sacramentos y toda forma de manifestación externa de religiosidad. A través de la óptica espiritual del Reformador, el hombre se justifica por la fe y no por sus obras. Sostuvo que la naturaleza humana está íntegramente corrompida y que la salvación provenía únicamente de la gracia de Dios dada a la criatura como regalo misericordioso. Para el fraile agustino de Erfurt, la voluntad del hombre era por tanto sierva de la voluntad divina. Propuso también la lectura individual de las Escrituras, sin necesidad de intermediarios.

Durante toda la época colonial, el discurso sobre Lutero partió de los esquemas impuestos por la retórica, es decir, del "arte de la persuasión" ${ }^{24}$ que determinó su recepción a lo largo de todo el periodo aludido, sólo con tenues destellos de cambio hacia finales del siglo XVIII. La retórica, que converge con la teología y con la historia, formuló una imagen acorde con los principios buscados y deseados por las elites eclesiásticas y políticas. El Reformador fue hecho un modelo narrativo para engendrar sentimientos de odio y originar en los receptores del mensaje un estado de conmoción y de rechazo a ciertas características a él impuestas. Llueven sobre él infamantes adjetivos: es maldito, perverso, vil. Comúnmente se refieren a él los autores como lobo, serpiente o cuervo. Por otra parte, los escritores de la era barroca se fijaron constantemente en las supuestas cualidades negativas del carácter del Reformador. Hacen alusión a su físico como el de "un sapo hinchado," 25 por parecer-

24 Sobre la invención de una figura retórica véase Borja, Jaime $\mathrm{H}$. 2002. Los indios medievales de fray Pedro de Aguado. Construcción del idólatra y escritura de la historia en una crónica del siglo XVI, Colombia: Centro Editorial Javeriano (CEJA).

25 Ribera Flores, D. 1600. Relación Historiada de las Exequias Funerales de la Majestad del Rey Philippo II Nuestro Señor...:140. México: Pedro Balli. les "beodo" de tanto beber cerveza y comer en exceso. ${ }^{26}$ Algunos le achacan falta de fuerza de voluntad, el haber llevado una vida licenciosa y se refieren a sus costumbres relajadas. Señalan que Lutero apoyaba la bigamia y que no podía controlar sus impulsos sexuales. Habiendo sido un fraile se había casado con una monja cisterciense exclaustrada, Catalina Bora, transgrediendo los votos impuestos por su hábito. ¡Había tenido además, cinco hijos! Este hecho daría pie a que se le condenara por lascivo, soberbio y pecador incorregible, inclinado por su debilidad, a caer en la concupiscencia de sus bajas y sensuales pasiones. ${ }^{27}$ Cuando se trataba de inmoralidad, se podía presentar su ejemplo. Luego le inventaron también una muerte horrorosa y llena de sufrimiento -digna del peor heresiarca- cuando en verdad murió plácidamente en su lecho, después de un súbito padecimiento. En fin, se pueden prolongar los ejemplos, reales o ficticios, sobre el doctor de teología de Wittenberg ad infinitum.

La imagen negativa de Lutero se construyó en el universo mental del "absolutismo confesional" del catolicismo de la Contrarreforma, ${ }^{28}$ a través del recurso del vituperio, que convirtió a Lutero en un arquetipo. Así, la estrategia de tratarlo como un objeto retórico derivó en la construcción de una imagen satánica.

Lutero no tuvo una relación directa con el mundo que lo juzgó, no hubo en términos generales en Nueva España un gran núcleo de protestantes y tampoco circuló su obra. Aún así, se le vio como enemigo, al hacerlo responsable del cisma de la Iglesia, por haber roto la unidad espiritual tradicional, lo que acarreó graves repercusiones en el orden político y en el económico. La crisis secular que trajo el protestantismo motivó la hiperdimensionalización de Lutero en un plano simbólico. El proceso de cristianización de la Contrarreforma encontró en el reformador alemán una especie de "chivo expiatorio" que formaría parte de esa guerra mental donde el bien y el mal se jugaban el destino del mundo.

Al darse la génesis de una concepción negativa de Lutero, que al fomentarse se convertiría en un estereotipo o en un mito antitético, al mismo tiempo surgió el ideal opuesto que serviría como base de identificación de lo propio, es decir, como un modelo o ejemplo. Mientras se inventaba a un Lutero como generador del veneno y la ponzoña, como la serpiente maligna que corrompía a Europa, se hacía a la par énfasis en la noción de Nueva España como un paraíso, libre de la sierpe tentadora, es decir, el lugar donde se cumplirían las promesas salvíficas, el escenario para la nueva historia de la Iglesia, donde la Reforma católica triunfaría sobre el mal de manera cabal. España era la elegida por la Providencia para salvar al mundo y sus reinos americanos serían el vergel del Imperio, el espejo de la realización de los ideales más elevados de la religión. América aparecería "purgada" de herejía; ésta sería aquí definitivamente desplazada, para dar

26 Engrava, Francisco, S.I., 1715. Orthodoxus contra orthodoxum, ca. 1715, Biblioteca Nacional de México, Fondo Reservado. Mss 390.

27 Oberman, Heiko. 1982. Lutero. Un hombre entre Dios y el Diablo: 343 y 339 Madrid: Alianza Editorial.

28 Rodríguez de la Flor, F. 2002. Barroco. Representación e ideología en el mundo hispánico: 170 Madrid: Editorial Cátedra. 
pie a una nueva y promisoria historia. Era éste un mundo donde incluso la Virgen María había elegido aparecer para proteger a los fieles y preservar esta tierra de la idolatría y de la contaminación herética. No es exagerado decir que la identidad novohispana se construyó de manera diferencial en el reconocimiento de la alteridad frente a los valores del protestantismo.

Como lo ha notado Solange Alberro, "el tema de la ortodoxia religiosa está en el meollo de la identidad mexicana." 29 La religión católica con su conjunto preciso de conceptos, prácticas, ritos y creencias fue uno de los medios para que los novohispanos buscaran una identidad propia y llenaran de sentido esta tierra. El énfasis en la práctica de los sacramentos, el culto mariano, la veneración a los santos e imágenes, las indulgencias, reliquias, procesiones, el valor de la Iglesia como intermediaria y las manifestaciones de religiosidad colectiva, es decir, todos los elementos defendidos por la Contrarreforma, se desplegaban contra ese otro mundo, el protestante, que los rechazaba. Los españoles que se establecieron en estas tierras y luego sus descendientes, los criollos, se definieron a sí mismos contra los valores del protestantismo y frente a Europa como mundo escindido por el cisma.

El criollismo jugó un papel esencial en la defensa y promoción de los valores contrarreformistas. El español nacido en América se legitimó a través de la religión católica, de la herencia hispana y del pasado indígena. Especialmente de 1630 a 1730, desplegó una religiosidad fincada en el amor a la tierra, en rasgos locales, que se alimentaba de la espiritualidad jesuita, que necesitaba de visiones, de hechos prodigiosos, reliquias e imágenes milagrosas. ${ }^{30}$ Se volcó en una abierta forma de piedad, buscó que la Santa Sede proclamara santos patronos oriundos de Nueva España y se aferró a ciertos usos y costumbres.

El criollo esgrimiría la noción de que México era un paraíso, una tierra de promisión para la realización de la historia providencial, y sostenía la visión de que la Iglesia en Indias era superior, incluso, a la de Roma, lastimada por los ataques de los cismáticos y las incursiones militares. Por el contrario, se insistiría en que esta tierra fuera vista como el lugar donde no habían cundido las herejías, donde no se habían propagado los falsos errores, donde se realizaría en su totalidad el proyecto de la nueva catolicidad reformada, libre de la contaminación espiritual. El virreinato de México se levantaría como mundo nuevo, como esperanza y salvación del cristianismo. Sus pobladores sintieron como un deber filial el sanar la vieja herida espiritual e histórica que la Reforma causó a la madre patria y, por extensión, a la propia colonia. Los criollos insistieron en que la magnífica obra del cristianismo en América era llevada adelante especialmente por ellos y que luchando contra las legiones del

29 Alberro, Solange. 1992. Del gachupín al criollo o de cómo los españoles de México dejaron de serlo: 45 México: El Colegio de México, 1992 (Jornadas, 122).

30 Rubial, Antonio. 1997. "Los santos milagreros y malogrados de la Nueva España", en C. García Ayluardo y Manuel Ramos (coords). Manifestaciones religiosas en el mundo colonial americano: 57 México: Instituto Nacional de Antropología e Historia, Universidad Iberoamericana, Centro de Estudios de Historia de México Condumex. mal cumplían no sólo con el mandato imperial de la corona y de la Iglesia, sino, sobre todo, con el de Dios.

\section{LA APLICACIÓn del CONCILIO de TRENTO en MÉXICO}

\section{Los concilios}

Los Concilios Provinciales en América fueron instrumentos comprensivos, coherentes y poderosos de la reforma y la evangelización e influyeron en el pensamiento y en la vida cotidiana de los americanos. Señalaron la reforma moral e intelectual del clero, a la que le seguiría la del resto de la sociedad; se dictaron leyes para españoles e indios, se establecieron normas de usos y costumbres, procedimientos para la predicación y catequesis. Abordaron temas de evangelización, lo referente a la administración de los sacramentos y diversas situaciones del mundo indígena, lo que se explica por las circunstancias americanas donde existían problemas apremiantes. Cabe observar que, a fines del siglo XVI y principios del XVII, habían sucedido drásticos cambios en la vida colonial por el proceso de desestructuración de las antiguas comunidades indígenas y sus tradiciones, que generaron nuevas conductas sociales, religiosas, económicas y conflictos de poder. ${ }^{31}$ Podemos decir que el primer objetivo de la reforma en América, después de la catequización de los indios, fue su pretensión depuradora y de mejoramiento del estado cristiano, en todos los niveles de la vida religiosa y, después de alcanzarse esta meta, se podría ya dar paso a la defensa de la religión católica frente al protestantismo.

El papa Pablo III (1534-1549), quien había convocado el Concilio de Trento, mostró interés por los temas americanos. Creó diez diócesis y la primera gran organización eclesiástica americana al erigir tres provincias eclesiásticas independientes. También es conocido por sus famosas bulas y breves a favor de los indios. ${ }^{32}$ A pesar de que los problemas de la Iglesia americana no se discutieron en Trento, el Concilio tuvo un fuerte impacto en Nueva España donde el espíritu tridentino encontró una expresión definida. Las disposiciones tridentinas fueron expedidas por el papa Pío IV en junio de 1564, con el breve In principio apostolarum sede. Poco después, Felipe II emitió una cédula real para ordenar obediencia a los decretos de Trento en todos sus reinos, sin menoscabo, empero, de sus derechos reales.

El Segundo Concilio Mexicano de 1565 incorporó ya la legislación tridentina en Nueva España, ${ }^{33}$ pero fueron las conclusiones del Tercero, llamado por Stafford Poole "el

31 Pastor, María A. 1996. Crisis y recomposición social. Nueva España en el tránsito del siglo XVI al XVII: 3 México: Fondo de Cultura Económica.

32 Castañeda, Paulino y J. Marchena Fernández. 1992. La jerarquía de la Iglesia en Indias: 168 Madrid: Mapfre.

33 Pérez Puente, Leticia, et.al. 2005 "Los concilios provinciales mexicanos primero y segundo", en Los Concilios Provinciales en Nueva España. Reflexiones e influencias: 17-40 México: Universidad Nacional Autónoma de México, Instituto de Investigaciones Históricas, Benemérita Universidad Autónoma de Puebla. Saranyana, Josep I. (ed). Teología en América Latina I: 137 Madrid-Frankfurt: IberoamericanaVervuert. Poole, Stafford. 1990: 549. 
Trento mexicano" ${ }^{134}$ convocado por el arzobispo Pedro Moya de Contreras en $\mathbf{1 5 8 5}$, en que sistemáticamente se hace referencia a los decretos del gran Concilio italiano. Las disposiciones no fueron ratificadas por el rey de España hasta 1591, por lo que perdería gran parte de su impacto a causa de la dilatación en la impresión de las actas, que fueron publicadas hasta 1622 y sólo hasta entonces, se empezaron a propagar sus conclusiones al nivel general de la población. En el curso de estos años, se pasó de la organización misional a la verdadera institucionalización de la iglesia mexicana. ${ }^{35}$ El programa tridentino para México consistió, además de lo dicho, en implantar la exacta observación del culto divino, reformar las ceremonias religiosas, establecer las prácticas doctrinales en los días festivos, cuaresma y adviento, celebrar las misas pontificales, uniformar la decencia del hábito del coro o rezo común, enriquecer el ornato de la Iglesia, reedificar conventos, visitar pueblos y diócesis, introducir la mayor economía en los gastos eclesiásticos sin menguar la dignidad episcopal, examinar y corregir las ordenanzas de las congregaciones, evitar los peligros y nulidades en la administración de los sacramentos, poner en práctica las constituciones apostólicas y el derecho canónico, que la reforma fuese disciplinar y canónica y la propagación de la doctrina se hiciera adecuadamente, así como obedecer los decretos episcopales, ver por la salud espiritual del clero y la virtud moral cristiana.

Con éstas disposiciones, el carácter monástico de la Iglesia cedió paso a una institucionalización de acuerdo con las nuevas normas que configuraron a su vez una organización eclesiástica sometida formalmente a la autoridad de los obispos, a una exigente ortodoxia, a una práctica piadosa intensa y a una atrayente visualidad. ${ }^{36}$ La orientación católica debía entenderse en la obra de conversión y edificación de un nuevo mundo y una nueva iglesia. En América, fue menester revisar dos temas: 1) Las singulares circunstancias

34 Poole, Stafford, 1987. Pedro Moya de Contreras. Catholic Reform and Royal Power in New Spain. 1571-1591: cap. X Berkeley: University of California Press. Martínez López-Cano, et. al. (coords). 2005. Los Concilios Provinciales en Nueva España. Reflexiones e influencias: 41-70 México: Universidad Nacional Autónoma de México, Instituto de Investigaciones Históricas, Benemérita Universidad Autónoma de Puebla.

35 Según Álvaro Huerga, la aportación del clero secular a la evangelización fue escasa, pero su aportación a la eclesialización fue masiva. Huerga, A. 1990. "Las órdenes religiosas, el clero secular y los laicos en la evangelización americana”, en Josep I. Saranyana, P. Tineo y Antón Pozas (eds), Evangelización y Teología en América (siglo XVI): 595 Pamplona: Universidad de Navarra. Sobre esto último, cabe hacer un paréntesis para ver la propuesta de John F. Schwaller, quien sugiere que en este desarrollo hay tres periodos reconocibles en el siglo XVI en que la Iglesia cambió notablemente. Uno temprano (de la conquista a 1540), marcado por la presencia de los conquistadores y los misioneros; un segundo periodo de expansión (1540-1575), caracterizado por el fin de la actividad puramente misional, por el desarrollo de las parroquias y de la burocracia eclesiástica; y una iglesia de madurez (desde 1575), determinada por los decretos del III Concilio Mexicano (1585) en que se establecieron normas eclesiásticas para la vida diaria de la Colonia y para la reforma del clero. Schwaller, John F. 1987. The Church and Clergy in SixteenthCentury Mexico: 226. Albuquerque: University of New Mexico Press.

36 Prien, Hans-Jürgen. 1985. La Historia del Cristianismo en América Latina: 248 Salamanca: Ediciones Sígueme. Gómez Piñol, E. 1991. “El arte indiano del siglo XVII: Del orden visual clásico al 'océano de colores'”, en Luis Navarro García (coord). Historia de las Américas II. II: 699719 Madrid- Sevilla: Universidad de Sevilla, Alhambra Longman. en las que se expandía el cristianismo y 2) Aplicar, adaptar y adecuar los decretos tridentinos al complejo ámbito del Nuevo Mundo.

Vistos ambos temas en conjunto, debe entenderse que América era tierra de misión, lo que también marca nuevos derroteros para este ámbito de la cristiandad. Uno de los fines principales de las reuniones conciliares era salvar almas, por lo que las metas apremiantes se fijaron para enseñar la religión cristiana a los indios, encaminar la labor de la evangelización con bases ideológicas y morales de la nueva orientación religiosa y llevar a cabo la obra social respectiva en estas comunidades buscando la salvación de sus almas. Además de dilatar la fe cristiana, había que velar por el aprovechamiento de los indios y protegerlos de la explotación. Se temía que, siendo los naturales "plantas tiernas en la fe", recibieran mensajes doctrinales equivocados y se tendió a vigilar la recepción del catolicismo en ellos. Se advertía a los predicadores de "no tratar de controversias o dificultades contra la fe, ni referir opiniones de herejes, aunque sea para confrontarlos por el daño que de eso se puede seguir de la gente vulgar". ${ }^{37}$ Con estas medidas se daría pie a la uniformidad en la enseñanza de la doctrina y del culto según los esquemas de la corona. Después de 1555, cuando terminó la primera evangelización novohispana y empezó la jerarquización de la Iglesia en América, ésta emprendió su mayor labor de adoctrinamiento ya sobre todos los grupos sociales de Nueva España. Respondió así a una misión al mismo tiempo civilizadora, evangélica y de búsqueda de poder. Desde la ciudad de México se orquestó el movimiento de cristianización impuesto por los imperativos de la Contrarreforma española y a ésta siguieron Guadalajara, Durango, Puebla, Querétaro, Zacatecas, Valladolid, Oaxaca, Veracruz, San Luis Potosí, y otros lugares.

El sistemático esfuerzo misional, doctrinal y catequético de España rindió frutos permanentes en las tierras conquistadas y colonizadas de América. En los albores del siglo XVII, en los principales centros urbanos, campeaba la visión católica del mundo entre los habitantes españoles y sus descendientes, los criollos, así como entre los mestizos $y$, con variantes importantes, entre la mayoría de los pueblos indígenas del centro de México. A lo largo de la historia colonial, no encontremos un solo caso de protestantismo entre los indios. Se prohibió que fueran ordenados sacerdotes, se empezó a limitar el aprendizaje del catecismo en lenguas indígenas, se les excluyó de las lecturas de los sagrados textos. El capelo que los protegió fue resistente a la posible recepción de otra confesión. Juan de Palafox describía cómo los naturales recibían dócil, suave y sencillamente la fe, mientras que en Europa "nacían monstruos horribles de heresiarcas y herejías que molestaron y persiguieron a la Iglesia poderosa y despiadadamente". ${ }^{38}$ Otro asunto fue el de las idolatrías, prácticas mucho más difíciles de extirpar, por su carácter ancestral. No obstante, el Primer Concilio Provincial Mexicano y, sobre todo, el Tercero, hicieron hincapié en este tema. Uno de las obligaciones principales de los sacerdotes párrocos -como lo ha estudiado Magnus

\footnotetext{
37 BLB, 266, Libro I.

38 Palafox y Mendoza, J. 1946: 62.
} 
Lundberg- era evitar que los indios volvieran a sus idolatrías. No podían ostentar adornos ni atavíos de la época previa a la conquista, cantar o bailar dentro de las iglesias según sus antiguos rituales, sus ídolos y templos debían ser "completamente destruidos", no podrían vivir dispersos en las montañas, sino ser congregados en pueblos. ${ }^{39}$

Sin embargo, es cierto también que, a pesar del impulso por implantar las instituciones hispánicas, se fue conformando un mundo complementario y semejante en muchos sentidos al de la España, pero también opuesto en otros aspectos. Dicho de otra manera, se pueden encontrar bases comunes compartidas entre las colonias y la metrópoli, pero el mundo colonial apuntó también al desarrollo de planteamientos independientes, de acuerdo con sus propias circunstancias históricas.

\section{El clero}

Según Melquíades Andrés, "la verdadera protección y cordón sanitario en tiempo de Carlos V y de Felipe II no la constituye principalmente el sistema de vigilancia (del Estado-Iglesia español) sino el florecimiento de una teología metódicamente renovada, que aborda los temas más importantes de la vida religiosa" ${ }^{40}$ A ello se unía un afán de reforma en las órdenes religiosas ${ }^{41}$ y el episcopado, así como una espiritualidad rica en vida interior. Se pensaba que el antídoto para combatir el mal de la herejía era la observancia estricta de las prácticas definidas por la Iglesia. La actitud contestataria al protestantismo llegó a la Nueva España con los teólogos que se trasladaron a América y que se metieron de lleno y en forma oficial en lo más vivo de los problemas doctrinales de la Vieja Europa. Tal fue el caso de personalidades como Diego Valadés, Pedro de Pravia y Juan de Ledesma. Hablamos de hábiles sistematizadores, la mayoría criollos, que influyeron en la cultura con estudios de gramática, retórica, metafísica, teología, lógica y didáctica desde los colegios, los claustros y la universidad. En sus escritos aparecerán ricas metáforas, complicadas alegorías, eruditas alusiones a textos clásicos, bíblicos y patrísticos y, por supuesto, posturas contra la herejía. A mediados del siglo XVI, el tema de la fe y la salvación se discutió tanto en la Universidad de Salamanca como en la de México, haciendo que América se hiciera presente en las tareas culturales de la Contrarreforma europea.

Los clérigos llegaron a ser el grupo más destacado de la sociedad virreinal. Siempre sujetos a la corona, su control

39 Magnus Lundberg 2011, Church Life between the Metropolitan and the Local. Parishes, Parishoners and Parish Priests in SeventeenthCentury Mexico, especialmente los capítulos "Trent comes to Mexico": 59-77 y "Unearth the hidden: Extirpation Records": 145-172.

${ }^{40}$ Andrés Martín, Melquíades 1985. "La imagen de Lutero en España hasta 1599", en José Belloch Zimmerman y Ángel Rodríguez (eds). Lutero y Reforma: 73 Cáceres: Universidad de Extremadura, Banco de Santander.

${ }^{41}$ Las órdenes religiosas, que, como se sabe, tuvieron un papel histórico determinante en el mundo colonial, respondieron a la política de la Contrarreforma, impuesta por Roma y por el estado español, de distintas maneras a lo largo de la historia colonial, mas no es éste el espacio para abundar en tan ingente y complejo análisis. Véase nota 9. sobre la doctrina, la liturgia y la moral, y a través de ellos sobre el arte, la imprenta, la educación y la beneficencia dieron a la Iglesia una excepcional influencia social y cultural. Herederos de la catolicidad postridentina, los eclesiásticos novohispanos se consideraron a sí mismos como los únicos que podían atajar la herejía y mantener la ortodoxia. Además, fueron los forjadores de la piedad y de la religiosidad populares a través de sus escritos, de la fundación de cofradías, la organización de fiestas, la predicación de homilías, llevando a cabo confesiones y dirección espiritual. ${ }^{42}$ Muchos miembros del clero novohispano observaron una religiosidad sincera y profunda, que se manifestó en la piedad, la caridad, la ayuda al prójimo, la erudición bíblica y patrística así como en la práctica de formas externas de culto y devoción.

La Contrarreforma tuvo profundas exigencias doctrinales que subsanaron estos teólogos cuyas metas fueron revelar la verdadera fe, incrementar la eficacia del mensaje católico y aclarar los principales puntos en estas materias. Estos autores se valieron también de los grandes ideólogos de la Contrarreforma, como Luis de Molina y Francisco Suárez, quienes se convirtieron en los fundamentos indiscutibles de estas obras y que así tuvieron una profunda resonancia pedagógica, metafísica y teológica en la Nueva España.

La teología en la Nueva España trató de configurar y afianzar la unidad religiosa y política del Imperio apoyando una política cultural amplia e igualmente unificante. Se trataba de una teología académica, en la que tomaron parte tanto los españoles pasados a América, como los criollos que desarrollaron su magisterio o participaron en importantes reuniones eclesiásticas.

Si bien la Contrarreforma fue el proyecto religioso y político de la corona, sin embargo, en Nueva España en realidad nunca se dio una completa unidad de doctrina y sí una diversidad de pensamiento que coexiste, dándole a la época intensa fecundidad. ${ }^{43}$

Es menester destacar el papel que jugó la Compañía de Jesús en la conformación de la ideología contrarreformista. La orden llegó a la Nueva España en 1572. Desde entonces, el clima ideológico y el patrimonio de la cultura se vieron influidos grandemente por las actividades de sus miembros que dejaron una fuerte impronta en la cultura novohispana con la fundación de colegios, con su participación activa en la docencia, su labor misional sobre todo en las tierras más inhóspitas de la Nueva España, y sus grandes contribuciones teológicas. ${ }^{44}$ En el periodo de mayor dinamismo de la orden, 1550-1650, que se le ha llamado "Renacimiento católico", se da con más ímpetu la renovación de la iglesia romana y de la teología. ${ }^{45}$ Los jesuitas fueron reflejo de la nueva eficacia

42 Rubial, Antonio. 1999: 54.

43 Kuri Camacho, Ramón. 1996. La Compañía de Jesús. Imágenes e ideas. La axiología jesuita, Juan de Palafox y Mendoza y otros estudios novohispanos: 186 México: Instituto Nacional de Antropología e Historia, Universidad Autónoma de Zacatecas, Universidad Autónoma de Puebla.

44 Decorme, Gerard, S.J., 1941. La obra de los jesuitas mexicanos durante la época colonial (1572-1767): 178 México: Antigua Librería Robredo.

45 Delumeau, Jean, 1973. El catolicismo de Lutero a Voltaire: 45-47 Barcelona: Editorial Labor. 
cristiana y del espíritu metódico aplicado al apostolado. Los discípulos de Ignacio de Loyola dieron ejemplo del ejercicio ascético incesante ${ }^{46}$ que dio importantes. Pusieron el acento en la actividad, en las obras, en las instituciones. Sobre todo, persiguieron la idea del triunfo total y absoluto de la Iglesia católica sobre la herejía que equivalía a decir el triunfo de la Contrarreforma sobre la Reforma protestante. En la bula de canonización de San Ignacio (1622) se hacía la mención de los dos frentes de batalla donde los jesuitas iban a sobresalir: en la cruzada contra la idolatría en el continente americano y en la lucha contra el cisma en el europeo:

En la época en que fueron descubiertos nuevos mundos y en el Viejo se levantó Lutero para combatir a la Iglesia Católica, tuvo Ignacio de Loyola la idea de fundar una Compañía que se había de dedicar preferentemente a la conversión de los paganos y al rescate de los herejes [...] por esta razón ha venido a aumentar la lista de los santos. Iglesias y altares, donde se celebra el sacrificio divino. ${ }^{47}$

A mediados del siglo XVII, la rivalidad con los protestantes se dejaba sentir, sobre todo, en el terreno de los logros misioneros. El jesuita Andrés Pérez de Ribas, notable evangelizador en el norte de México, se ufanaba del número de conversiones católicas que sus hermanos de hábito llevaban a cabo en todo el mundo.

Los Padres de la Compañía, por medio de sus misiones, han convertido a nuestra Santa Fe más de 200 mil personas: y hasta el mismo año en Bohemia y Ungría, y en las Provincias circunvecinas, predicando los jesuitas contra los errores de Lutero y Calvino y caterna de hugonotes han reducido al gremio de la Iglesia más de 40 mil hereges. ${ }^{48}$

Los jesuitas mexicanos hicieron observaron diferentes estrategias para transmitir los mensajes religiosos de la Iglesia católica tridentina entre los fieles y aprovecharon la oportunidad que brindaban el arte, la prédica, los escritos confesionales y aún las representaciones teatrales para comunicar su ideología.

\section{Arte, retórica y doctrina}

Como lo señaló Werner Weisbach hace ya tiempo, la Contrarreforma se expresó a través del barroco. ${ }^{49} \mathrm{El}$ movimiento propició medios de comunicación sumamente

46 Los jesuitas también son ejemplo de esa forma de piedad que Max Weber llama "intramundana", aunque el autor sólo distingue con ella a la ética protestante. Weber, Max 1958. The Protestant Ethic and the Spirit of Capitalism, New York: Charles Scribner \& Sons.

47 Bullarium Cocquelines, en Ranke, Leopold von. 1943. Historia de los Papas: 430 México: Fondo de Cultura Económica. Ranke lleva a cabo una interesante comparación entre Lutero y Loyola Ibidem: 90-92.

48 Pérez de Ribas, Andrés, [1896] 1992. Historia de los Triunfos de Nuestra Santa Fe: ix-x México: Siglo XXI Editores.

49 Weisbach, Werner. 1942. El barroco, arte de la Contrarreforma: pasim Madrid: Espasa Calpe. Fernando R. de la Flor fecha el barroco en España de 1580, momento en que la reorganización tridentina comienza a entrar en su fase de clímax. Rodríguez de la Flor, F. 2002: 23. Por su parte, José A. Maravall afirma que se da con más intensidad en España de 1605 a 1650. Maravall, José Antonio, 1975. La cultura del barroco: 34 Barcelona: Ariel. En Nueva España, este movimiento es perceptible en los ámbitos urbanos ya claramente después de 1620 y se prolonga hasta la tercera década del siglo XVIII. convincentes y performativos. El arte fue uno de los instrumentos de propaganda del catolicismo de acuerdo con las directrices impuestas por la Santa Sede y los jesuitas. ${ }^{50}$ Los temas más comunes representaban símbolos al servicio del dogma: enaltecer a la Ecclesia triumphans, luchar contra el pecado, desacreditar al protestantismo, exaltar los sacramentos, comunicar correctamente la doctrina cristiana y propagar la fe. Existe, incluso, una interesante iconografía en Nueva España donde se ostenta Lutero simbólicamente, quien se distingue generalmente en las pinturas por llevar su nombre junto a la figura que lo representa, con los elementos anatematizantes del hereje.

Otro medio imprescindible de afirmación de la cultura de la Contrarreforma fue el sermón, a través del cual se estableció una comunicación oral a un gran público, congregado en los templos. La imagen y el sermón formaron una mancuerna inseparable capaz de transmitir una serie de mensajes a través de la simbología, la alegoría y los fundamentos religiosos del catolicismo. A través de la oratoria sagrada llegó la aviesa e interesada propaganda antiluterana a un gran público que no tenía acceso a las fuentes teológicas o que no leía otro tipo de literatura, ya fuera por el alto índice de analfabetismo que entonces existía o por no tener acceso a las obras de los intelectuales e historiadores. Para el público culto, estaban las autoridades en latín y el arte emblemático que exigía de una compleja interpretación, mientras que el común de la gente percibía las nociones que querían transmitirle los ideólogos a través del púlpito y de las manifestaciones estéticas. En ambos casos los contenidos eran cuidadosamente meditados y la comunicación al gran público se establecía también con reglas y métodos muy precisos, de acuerdo con los lineamientos del programa contrarreformista.

Otro de los medios que sirvieron para propagar los ideales tridentinos fue el catecismo. El III Concilio Mexicano (1585) estipulaba que la doctrina cristiana debía transmitirse a través del catecismo aprobado por Trento, en castellano para españoles, mulatos y negros y, para los indios, "en su mesma lengua natural". ${ }^{51}$ Muy difundida fue La Doctrina Cristiana de Jerónimo de Ripalda, obra de gran importancia, difusión e influjo en la Colonia que fue un factor de unidad cultural en medio de la diversidad que caracterizó a la Nueva España. En ese catecismo se atacaba la figura de Lutero y se reafirmaba la doctrina cristiana en contraposición con los argumentos protestantes, aunque sin hacerse referencia directa a ellos, para no generar el efecto contrario, motivar la discusión de temas delicados.

50 Sebastián, Santiago. 1989. Contrarreforma y barroco: 13 Madrid: Alianza Editorial. Weisbach, W. 1942: 89. Mariscal, Beatriz. 2001. "El programa de representación simbólica de los jesuitas en Nueva España”, en José Pascual Buxó (ed). La producción simbólica en la América Colonial: 51-66 México: Universidad Nacional Autónoma de México.

51 BLB, M-M 266. Resines, Luis.1994 "Los catecismos del siglo XVI y su modo de presentar la fe", en Anuario de Historia de la Iglesia, vol. III: 197-213 Universidad de Navarra, Instituto de Historia de la Iglesia, Facultad de Teología. Sánchez Herrero, José. 1994. "Los catecismos de la doctrina cristiana y el medio ambiente social donde han de ponerse en práctica (1300-1550)", en Anuario de Historia de la Iglesia, vol. III: 179196 Universidad de Navarra, Instituto de Historia de la Iglesia, Facultad de Teología. 
Después del siglo XVI, las autoridades eclesiásticas prefirieron la difusión de catecismos europeos en la Nueva España a los manuales o tratados para indígenas en lengua vernácula. Como el catecismo se aprendía de memoria, los valores centrales que esgrimía eran transmitidos por este arte y permeaban así en la psique de la sociedad novohispana. Las ideas en él contenidas influyeron, no sólo en la conciencia de los escritores del momento, quienes, desde México, trataban de dar explicación filosófica a la crisis del mundo europeo resultante de la pugna Reforma-Contrarreforma, sino, más importante aún, en el pueblo, habilitándolo para aprehender los esquemas de pensamiento impuestos por el catolicismo postridentino.

\section{La Inquisición}

La alarma despertada por la posible difusión de la herejía en el Nuevo Mundo, primero criptojudía y luego luterana, y la necesidad de sanear la moralidad pública en estos reinos fue determinante en la decisión de la corona de solicitar la erección en Indias del Tribunal del Santo Oficio con características similares al existente en la Península. Así, se llevó a cabo el control de la penetración ideológica y la infiltración extranjera.

En España, inmediatamente después de la proclamación de la doctrina luterana, el Santo Oficio desarrolló una estrategia de defensa. Luego, el espíritu inquisitorial avivado por la Contrarreforma buscó anidarse en las colonias españolas de América por la encomienda expresa de Felipe II en este sentido. La implantación en México del Tribunal del Santo Oficio en el año de 1571 se dio con el propósito de defender la religión y la cultura católica de quienes seguían ideas heréticas y no respetaban los principios religiosos.

El temor a la heterodoxia que desde temprano mostraron las jerarquías fue un factor decisivo para la implantación del tribunal americano, aunque éste se estableció cuando ya habían pasado los años de pánico por la penetración de esta confesión entre amplios sectores de la Península (1540 y 1558) y había amainado su carácter ultra represivo. Tal vez esto haya motivado al historiador Irving Leonard a decir que la Inquisición mexicana se caracterizó por una moderación inesperada. ${ }^{52}$ Las circunstancias americanas, distintas a las de la Península, ${ }^{53}$ cambiaron el rumbo de los objetivos iniciales hacia la vigilancia de la moral y de la conducta y la institución acabó siendo un medio de control, normalización y estabilización social. ${ }^{54}$

52 Leonard, Irving 1986. La época barroca en el México colonial: 155 México: Fondo de Cultura Económica.

53 Werner Thomas, quien ha llevado a cabo un importante estudio sobre la Inquisición en España, informa que en la Península, entre 1517 y 1648 hubo más de 2500 extranjeros acusados de luteranismo por la Inquisición. Thomas, Werner. 2001. La represión del protestantismo en España, 1517-1648: viii Lovaina: Leuven University Press. En México no hay un equivalente a esta cifra, pues los efectos de esta confesión fueron tardíos y se diluyó la aspereza de la persecución contra éstos en comparación con España. Ver Gringoire, Pedro: 1961.

54 Alberro, Solange. 1988. Inquisición y sociedad en México. 15711700: 150. México: Fondo de Cultura Económica.
La Inquisición evolucionó y cambió los focos de su atención, sus procedimientos y sus objetivos a lo largo de sus casi 300 años de existencia ${ }^{55}$ En el siglo XVI, despunta "la fase protestante", como la ha definido William Taylor ${ }^{56}$, caracterizada por su afán persecutorio, su actitud defensiva y la dureza en los castigos. En la siguiente centuria, disminuye el temor por parte de la Inquisición de que el protestantismo cundiera por todo el Imperio. En esta época, decrece lo severo de las penas, baja el celo proselitista protestante, ${ }^{57}$ aunque, por otro lado, no amaina el sentimiento de aspereza contra los judaizantes. Para la era dieciochesca tardía, el "problema protestante" no era considerado tan urgente, pues el Santo Oficio haría frente a problemas cruciales de la política internacional. Por esta razón mostró cierta negligencia o laxitud en la persecución de los sospechosos, no por ineficiencia, como prueba el historiador estadounidense, sino por necesidad de atender a cuestiones diplomáticas que se consideraron apremiantes.

El Tribunal hizo énfasis en el "problema" protestante en el primer gran auto de fe público de 1574 celebrado en la ciudad de México. Allí fueron relajados cinco "luteranos", designación por demás ambigua que incluía toda confesión protestante. Parece que una gran parte del sentimiento antiprotestante se engendró con estas ceremonias, que fueron fuente de información transmitida al pueblo que se congregaba en las plazas. El poder de la Inquisición se expresaba en un nivel colectivo, con gran concurso de gente, con los cuerpos institucionales y las autoridades virreinales presentes. Los autos de fe se caracterizaron por su gran riqueza representativa y emocional. Incidían honda y eficazmente en la conciencia del pueblo de un modo indeleble y patético.

Muchos pseudoprotestantes vinieron a Nueva España durante los primeros cincuenta años de la colonia. ${ }^{58} \mathrm{Se}$ utilizó entonces el término genérico de "luteranos" para señalarlos, pero a veces los actos y creencias de aquellos individuos no tenían relación alguna con las propuestas del reformador de Wittenberg. Por otra parte sí hubo individuos que tenían muy clara la propuesta del reformador alemán y comulgaban con ella, pero éstos fueron muy pocos y, en abrumadora mayoría, forasteros: franceses, alemanes, flamencos, holandeses, bohemios e ingleses. El carácter aislado, no amenazante, de estas personas, que no buscaban hacer proselitismo sino desenvolverse en actividades comerciales, hizo que el Tribunal observara "un grado significativo de flexibilidad". ${ }^{59}$ A pesar de que en 1632, el jesuita Álvaro Arias aseguraba que "los libros de los herejes vienen de ordinario de allende el mar, para pegar su malicia donde

55 Se estableció en México en 1522, pero formalmente hasta 1571 y se mantuvo hasta 1820 . De junio de 1813 a diciembre de 1814 estuvo suprimida.

56 Taylor, William B. 1965. Protestants Before the Inquisition in Mexico. 1790-1820: 36 tesis de maestría, Puebla- México, Universidad de las Américas, Agosto de 1965.

57 En el siglo XVI, 67 protestantes fueron traídos ante la Inquisición y 8 fueron relajados (pena de muerte en la hoguera). En el XVII, hubo 50 casos y 4 relajados. En el XVIII, sólo algunos fueron quemados en efigie. Taylor, William B. 1965: 34-35.

58 Greenleaf, Richard. 1981. La Inquisición en Nueva España. Siglo XVI: 92 México: Fondo de Cultura Económica.

59 Taylor, William B. 1965: 7. 
no nacieron como una plaga de langostas", 60 y de que existen datos de que los libros prohibidos circulaban en América (es probable que hayan llegado algunos por las costas o las fronteras del norte), empero, no tenemos indicios de que las obras de Lutero formaran una anegante literatura en la Nueva España. Al igual que en España, en las colonias se incautaron biblias junto con algunas obras litúrgicas y de devociones particulares. Al convertirse en objeto de la atención inquisitorial, la circulación de libros constituyó uno de los capítulos más originales sobre la incidencia del Santo Oficio en la piedad popular y en las formas exteriores de la religiosidad en aquellos días.

Julio Jiménez Rueda afirmó, con razón, que en Nueva España no hubo "heresiarcas de primera categoría". ${ }^{61} \mathrm{Se}$ dice, por el contrario, que la herejía fue sólo casual y ocasional, que ésta no floreció espontáneamente en la colonia y que lo que aquí se ve son prácticas adulteradas y certidumbres borrosas. ${ }^{62}$ Salvo un puñado de casos, no encontramos entre españoles, criollos y mucho menos entre mestizos e indígenas, algún seguidor que fuera con seguridad o fehacientemente un luterano. ${ }^{63}$

El cordón sanitario impuesto por el Santo Oficio en Nueva España fue eficaz: no hubo aquí un movimiento protestante organizado y con canales respetables de difusión. Para el siglo XVIII, Los protestantes no eran ya amenaza al orden establecido de la Iglesia o el Estado. Ahora se temía a otras ideologías como el jansenismo, el deísmo, la francmasonería, el ateísmo, el regalismo o el naturalismo. La política española a través de sus instituciones cumplió con su objetivo: evitó la herejía protestante en el Nuevo Mundo.

\section{BiBLIOGRAFÍA}

Archivo:

BLB Bancroft Library, Berkeley.

BNM Biblioteca Nacional de México (Fondo Reservado).

\section{Fuentes (primarias y secundarias):}

Arias, Álvaro, 1632. Publicación solemne (índice expurgatorio), Sevilla, Simón Faxardo.

Alberro, Solange, 1988. Inquisición y sociedad en México. 1571-1700, México, Fondo de Cultura Económica.

Alberro, Solange, 1992. Del gachupín al criollo o de cómo los españoles de México dejaron de serlo, México, El Colegio de México, (Jornadas, 122).

60 Arias, Álvaro, 1632. Publicación solemne (índice expurgatorio): 12 Sevilla: Simón Faxardo.

61 Jiménez Rueda, Julio. 1946. Herejías y supersticiones en la Nueva España (los heterodoxos en México), México: ix Universidad Nacional Autónoma de México, Imprenta Universitaria.

62 Alberro, Solange. 1988: 170.

63 Quizá tal vez uno, en todo el período colonial. Un religioso de Zacatecas, fray Francisco Manuel de Quadros, quien fue relajado en auto de fe del 20 de marzo de 1678 por ser "herege pertinaz, contumaz, luterano, calvinista, dogmatista" como rezaba su sambenito. Gringoire, Pedro: 167.
Andrés Martín, 1975. Melquíades, Reforma española y Reforma luterana, Madrid, Fundación Universitaria Española.

Andrés Martín, Melquíades 1985. "La imagen de Lutero en España hasta 1599", en José Belloch Zimmerman y Ángel Rodríguez (editores), Lutero y Reforma, Cáceres, Universidad de Extremadura, Banco de Santander: 55-85.

Balderas Vega, Gonzalo 1996. La Reforma y la Contrarreforma. Dos expresiones del ser cristiano en la Modernidad, México, Universidad Iberoamericana.

Blancarte, Roberto, 1999. Historia de la Iglesia Católica en México, México, Fondo de Cultura Económica-El Colegio Mexiquense.

Borja, Jaime Humberto, 2002. Los indios medievales de fray Pedro de Aguado. Construcción del idólatra y escritura de la historia en una crónica del siglo XVI, Bogotá, Colombia, Centro Editorial Javeriano (CEJA).

Brading, David, 1997. "La devoción católica y la heterodoxia en el México borbónico", en Clara García Ayluardo y Manuel Ramos (editores), Manifestaciones religiosas en el mundo colonial americano, México, Instituto Nacional de Antropología e Historia-Universidad IberoamericanaCondumex: 25-50.

Castañeda, Paulino y Juan Marchena Fernández, 1992. La jerarquía de la Iglesia en Indias, Madrid, Mapfre.

Contreras, J, 1984. (sin título), en Pérez Villanueva, Joaquín y Bartolomé Escadell Bonet (directores), Historia de la Inquisición en España y América, 2 ed., Madrid, Biblioteca de Autores Cristianos.

Decorme, Gerard, S.J. 1941. La obra de los jesuitas mexicanos durante la época colonial (1572-1767), México, Antigua Librería Robredo.

Delumeau, Jean, 1973. El catolicismo de Lutero a Voltaire, Barcelona, Editorial Labor.

Elton, Geoffrey R. 1963. Reformation in Europe. 15171559, London, Collins: 180-181.

Engrava, Francisco, S.I. ca. 1715. Orthodoxus contra orthodoxum, Biblioteca Nacional de México, Fondo Reservado. Mss 390.

Fernández, Álvarez, Manuel, 1998. Felipe Il y su tiempo, Madrid, Espasa Calpe.

Frost, Elsa Cecilia, 2002. La historia de Dios en las Indias, México, Tusquets Editores.

García Villoslada, Ricardo, 1959. "La Contrarreforma. Su nombre y su concepto histórico", en Saggi storici intorno al papato dei professori della Facoltá di Storia Eclesiástica, Roma, (Miscellanea Historiae Pontificae XXX, 1):189-242.

Gómez Canedo, Lino, 1977. Evangelización y Conquista, México, Porrúa.

Gómez Piñol, Emilio, 1991. "El arte indiano del siglo XVII: Del orden visual clásico al 'océano de colores'”, en Luis Navarro García (coordinador), Historia de las Américas II, Madrid- Sevilla, Universidad de Sevilla, Alhambra Longman, capítulo XIV: 699-719. 
González González, Enrique, 2005. “La ira y la sombra. Los arzobispos Alonso de Montúfar y Moya de Contreras en la implantación de la Contrarreforma en México", en María del Pilar Martínez López-Cano y Francisco Javier Cervantes Bello, Los Concilios Provinciales en Nueva España. Reflexiones e influencias, Universidad Nacional Autónoma de México, Instituto de Investigaciones Históricas, Benemérita Universidad Autónoma de Puebla.

Greenleaf, Richard, 1981. La Inquisición en Nueva España. Siglo XVI, México, Fondo de Cultura Económica.

Gringoire, Pedro (Gustavo Báez Camargo), octubre-diciembre 1961. "Protestantes enjuiciados por la Inquisición”, en Historia Mexicana, vol XI, núm. 2, México, El Colegio de México: 161-179.

Huerga, Álvaro, 1990. "Las órdenes religiosas, el clero secular y los laicos en la evangelización americana", en Josep I. Saranyana, P. Tineo y Antón Pozas (editores), Evangelización y Teología en América (siglo XVI), 2 vols., $X$ Simposio Internacional de Teología, Pamplona, Universidad de Navarra: 569-602.

Jiménez Rueda, Julio, 1946. Herejías y supersticiones en la Nueva España (los heterodoxos en México), México, Universidad Nacional Autónoma de México, Imprenta Universitaria.

Kuri Camacho, Ramón, 1996. La Compañía de Jesús. Imágenes e ideas. La axiología jesuita, Juan de Palafox y Mendoza y otros estudios novohispanos, México, Instituto Nacional de Antropología e Historia, Universidad Autónoma de Zacatecas, Universidad Autónoma de Puebla.

Lara Cisneros, Gerardo, 2005. "Los concilios provinciales y la religión de los indios en Nueva España”, en Pilar Martínez López Cano y Francisco Javier Cervantes Bello (coord), Los Concilios Provinciales en Nueva España. Reflexiones e Influencias, México, Universidad Nacional Autónoma de México-Instituto de Investigaciones Históricas-Benemérita Universidad Autónoma de Puebla: 203-222.

Lara Cisneros, Gerardo, 2015. "La lucha contra la superstición y las idolatrías en Nueva España y Perú. Siglo XVII", en José de la Puente Brunke y Alicia Mayer, Iglesia y sociedad en la Nueva España y el Perú, México, Lima Madrid, Analecta Editorial-Universidad Pontificia de Perú, Universidad Nacional Autónoma de México, Centro de Estudios Mexicanos: 123-152.

Leonard, Irving, 1986. La época barroca en el México colonial, México, Fondo de Cultura Económica.

Lundberg, Magnus, 2011, Church Life between the Metropolitan and the Local. Parishes, Parishoners and Parish Priests in Seventeenth-Century Mexico. Madrid, Frankfurt, Iberoamericana-Vervuert, 2011.

Lutz, Heinrich, 1983. Das Ringen um deutsche Einheit und kirchliche Erneuerung, 1490-1648, Berlin, Propyläen Verlag.

Maravall, José Antonio, 1975. La cultura del barroco, Barcelona, Ariel.

Mariscal, Beatriz, 2001. "El programa de representación simbólica de los jesuitas en Nueva España”, en
José Pascual Buxó (editor), La producción simbólica en la América Colonial, México, Universidad Nacional Autónoma de México: 51-66.

Martínez López-Cano, Pilar y Francisco Javier Cervantes Bello (coordinadores), 2005. Los Concilios Provinciales en Nueva España. Reflexiones e influencias, México, Universidad Nacional Autónoma de México, Instituto de Investigaciones Históricas, Benemérita Universidad Autónoma de Puebla.

Mayer, Alicia y María Alba Pastor (coordinadoras), 2000. Formaciones religiosas en la América colonial, México, Universidad Nacional Autónoma de México, Facultad de Filosofía y Letras.

Mayer, Alicia, 2008. Lutero en el paraíso. La Nueva España en el espejo del reformador alemán, México, Fondo de Cultura Económica.

Mora Mérida, 1990. "Reflexiones históricas acerca del pasado idolátrico hispanoamericano en el siglo XVI", en Josep I Saranyana, P. Tineo y Anton Pozas (coordinadores), Evangelización y Teología en América (siglo XVI), 2 vols., $\mathrm{X}$ Simposio Internacional de Teología, Pamplona, Universidad de Navarra: 689-694.

Morales Valerio, Francisco, 1973. Ethnic and SocialBackground of the Franciscan Friars in Seventeenth Century Mexico, Washington, D.C. Academy of American Franciscan History.

Nettel, Patricia, 1986. La utopía franciscana en la Nueva España, Universidad Nacional Autónoma de México.

O'Gorman, Edmundo, 1986. Destierro de sombras. Luz en el origen de la imagen y culto de Nuestra Señora de Guadalupe del Tepeyac, México, Universidad Nacional Autónoma de México.

Palafox y Mendoza, Juan, 1946. Ideas políticas, prólogo de José Rojas Garcidueñas, México, Universidad Nacional Autónoma de México, (Biblioteca del Estudiante Universitario, 64).

Pastor, María Alba, 1996. Crisis y recomposición social. Nueva España en el tránsito del siglo XVI al XVII, México, Fondo de Cultura Económica.

Pérez de Ribas, Andrés, 1992. Historia de los Triunfos de Nuestra Santa Fe, México, Siglo XXI Editores.

Pérez Puente, Leticia, Enrique González González y Rodolfo Aguirre, 2005. "Los concilios provinciales mexicanos primero y segundo", en Los Concilios Provinciales en Nueva España. Reflexiones e influencias, México, Universidad Nacional Autónoma de México, Instituto de Investigaciones Históricas, Benemérita Universidad Autónoma de Puebla: 17-40.

O'Gorman, Edmundo, 1986. Destierro de sombras. Luz en el origen de la imagen y culto de Nuestra Señora de Guadalupe del Tepeyac, México, Universidad Nacional Autónoma de México.

Oberman, Heiko, 1982. Lutero. Un hombre entre Dios y el Diablo, Madrid, Alianza Editorial.

Poole, Stafford, 1987. Pedro Moya de Contreras. Catholic Reform and Royal Power in New Spain. 1571-1591, Berkeley, University of California Press. 
Poole, Stafford, 1990. "Incidencia de los Concilios Provinciales Hispanoamericanos en la organización eclesiástica del Nuevo Mundo", en Josep I. Saranyana y P. Tineo (coordinadores), Evangelización y teología en América (siglo XVI), 2 vols., X Simposio Internacional de Teología, Pamplona, Universidad de Navarra: 549-551.

Prien, Hans-Jürgen, 1985. La Historia del Cristianismo en América Latina, Salamanca, Ediciones Sígueme.

Ranke, Leopold von, 1943. Historia de los Papas, México, Fondo de Cultura Económica.

Reinhard, Wolfgang, s/f. "Sozialdisziplinierung-Konfessionalisierung-Modernisierung. Ein historiographischer Diskurs", en Nada Boskvoska Leimgruber (editora), Die Frühe Neuzeit in der Geschichtswissenschaft. Forschungstendenzen und Forschungsergebnisse, Pader-born: 39-55.

Reinhard, Wolfgang 1977. "Gegenreformation als Modernisierung? Prolegomena zu einer Theorie des konfessionellen Zeitalters", en Archiv für Reformationsgeschichte, 68: 226-251.

Reinhard, Wolfgang, 1981. "Konfession und Konfessionalisierung in Europa", en: Bekenntnis und Geschichte. Die Confessio Augustana im historischen Zusammenhang, München, ed. por Wolfgang Reinhard: 226-252.

Reinhard, Wolfgang, 2001. "Das Konzil von Trient und die Modernisierung der Kirche", en: Prodi, Paolo y Wolfgang Reinhard (editoress), Das Konzil von Trient und die Moderne. Berlin: 23-42.

Resines, Luis, 1994. "Los catecismos del siglo XVI y su modo de presentar la fe", en Anuario de Historia de la Iglesia, vol. III, Universidad de Navarra, Instituto de Historia de la Iglesia, Facultad de Teología: 197-213.

Ribera Flores, Dionisio, 1999. Relación Historiada de las Exequias Funerales de la Majestad del Rey Philippo II Nuestro Señor... México, Pedro Balli, 1600. Hay edición moderna, con introducción de Ernesto de la Torre Villar, México, Bibliófilos Mexicanos.

Ricard, Robert, 1986. La conquista espiritual de México: Ensayo sobre el apostolado y los métodos misioneros de las órdenes mendicantes en la Nueva España de 1523-24 a 1572. Trad. de Ángel María Garibay, México, Fondo de Cultura Económica.

Rodríguez de la Flor, Fernando, 2002. Barroco. Representación e ideología en el mundo hispánico, Madrid, Editorial. Cátedra.

Rubial, Antonio, 1997. "Los santos milagreros y malogrados de la Nueva España", en Clara García Ayluardo y Manuel Ramos (coordinadores), Manifestaciones religiosas en el mundo colonial americano, México, Instituto Nacional de Antropología e Historia, Universidad Iberoamericana, Centro de Estudios de Historia de México Condumex: 51-87.

Rubial, Antonio, 1999. La santidad controvertida, México, Fondo de Cultura Económica.
Sáez-Arance, Antonio, 2001. “¿`Confesionalización' en la América Hispana? Observaciones sobre la aplicabilidad de un concepto", en Héctor Noejovich (editor), América bajo los Austrias. 50 Congreso Internacional de Americanistas 2000, Pontificia Universidad Católica de Perú: 75-80.

Saranyana, Joseplgnasi(editor), 1999. TeologíaenAmérica Latina, vol. I, Madrid-Frankfurt, Iberoamericana-Vervuert.

Schilling, Heinz, s/f. "Die Konfessionalisierung im Reich. Religiöser und gesellschaftlicher Wandel in Deutschland zwischen 1555 und 1620", en Historische Zeitschrift, 246: 1-45.

Schilling, Heinz, 1994. Aufbruch und Krise Deutschland 1517-1648. Das Reich und die Deutschen, Sonderausgabe in der Sammlung Siedler.

Schilling, Heinz, 1995. "Confessional Europe", en Thomas A. Brady, Heiko A. Oberman y James D. Tracy (editores), Handbook of European History 1400-1600. Late Middle Ages, Renaissance and Reformation, vol. II, Visions, Programs and Outcomes, Leiden, New York, Köln, E.J. Brill: 640-681.

Schilling, Heinz, 1981. Konfessionskonflikt und Staatsbildung. Eine Fallstudie über das Verhältnis von religiösem und sozialem Wandel in der Frühneuzeit am Beispiel der Grafschaft Lippe, Gütersloh.

Schilling, Heinz, 1995. "Die Konfessionalisierung von Kirche, Staat und Gesellschaft-Profil, Leistung, Defizite und Perspektiven eines geschichtswissenschaftlichen Paradigmas", en Heinz Schilling y Wolfgang Reinhard (editores), Die katholische Konfessionalisierung, Münster: 1-49.

Schwaller, John F. 1987. The Church and Clergy in Sixteenth-Century Mexico, Albuquerque, University of New Mexico Press.

Sebastián, Santiago, 1989. Contrarreforma y barroco, Madrid, Alianza Editorial.

Sánchez Herrero, José, 1994. "Los catecismos de la doctrina cristiana y el medio ambiente social donde han de ponerse en práctica (1300-1550)", en Anuario de Historia de la Iglesia, vol. III, Universidad de Navarra, Instituto de Historia de la Iglesia, Facultad de Teología: 179-196.

Tavárez, David, 2011, The Invisible War. Indigenous Devotions, Discipline and Dissent in Colonial Mexico, Stanford, California, Stanford University Press.

Taylor, William B. Agosto de 1965. Protestants Before the Inquisition in Mexico. 1790-1820, tesis de maestría, PueblaMéxico, Universidad de las Américas.

Thomas, Werner, 2001. La represión del protestantismo en España, 1517-1648, Lovaina, Leuven University Press.

Weber, Max, 1958. The Protestant Ethic and the Spirit of Capitalism, New York, Charles Scribner \& Sons.

Weisbach, Werner, 1942. El barroco, arte de la Contrarreforma, Madrid, Espasa Calpe.

Zeeden, Ernst Walter, s/f. "Grundlagen und Wege der Konfessionsbildung in Deutschland im Zeitalter der Glaubenskämfe", en Historische Zeitschrift, 185: 249-299. 